\title{
The Effect of frequent flyer programs on consumer be- havior in the German airline market
}

\author{
Mark Wever * \\ University of Latvia, Riga, Latvia
}

\section{Keywords}

Frequent flyer programs Consumer behavior

Airline market

Received: 25 July 2020

Accepted: 12 October 2020

Published: 15 December 2020

\begin{abstract}
This study evaluates the impact of FFP on consumer behavior. It assesses determiners and moderators of effective FFP design in a representative customer survey $(n=502)$ of Miles \& More members in Germany. The study finds that FFP impact all levels of the customer behavior chain, particularly customer attitude, brand image, booking behavior, customer loyalty, sustainable customer relationships, and passengers' value perception. FFP building blocks interact: Service, status, and monetary awards must be effectively combined to maximize customer impact. A broad and far-reaching partner network and transparent redemption options are essential to convince customers of the program's value. Airline safety and quality are additional essential determiners of customer booking and loyalty behavior. FFP mainly addresses frequently flying business customers on short-distance flights. Airlines should develop their programs to appeal to this customer group and ensure perceived FFP honesty by transparent and reliable redemption conditions and a comprehensive service package awarding loyal customers reliably.
\end{abstract}

(C) 2020 The Author(s). Published by TAF Publishing.

\section{INTRODUCTION}

\section{Motivation and Research Issue}

A wave of insolvency has been haunting the European aviation business: Already, from 2015 to 2017, three European Airlines (Monarch Airlines, Air Berlin, and Alitalia) have filed for insolvency. The present Corona Crisis has brought further market participants under significant pressure: Laudamotion will stop its operations by October 2020. Easyjet has reported the, most extensive annual loss in its history since 1995 (Airliners, 2020). Twenty-two thousand jobs are at stake at Lufthansa, although the company has been receiving extensive government support this year (Tagesschau, 2020).

Apart from the Corona-Virus shut down, European airlines face absolute and perpetual pressure from several directions: Due to the progressive deregulation of international flight markets and the decrease of fuel prices, rival lowcost carriers from around the globe have gained important market shares in Europe and account for $43 \%$ of the flights in 2017 (up from 9\% in 2002) (Powley, 2017). Airlines' leisure customers have been reducing their flight activity partly due to environmental reasons. About $50 \%$ of airline revenues are from $15 \%$ of most frequently flying customers. Appealing to and retaining frequent flyers is essential to airline survival and prosperity in an increasingly competitive market (International Air Transport Association, 2017; Kuo \& Chen, 2015).

Customer loyalty programs or, more specifically, "Frequent Flyer Programs" (in the following: FFP) have been designed to appeal to frequently flying and mainly commercial customers (Peacock, 2019). FFP offers customers, excelling by frequent or loyal booking behavior, exceptional amenities, status incentives or monetary awards, intending to keep these high potential clients loyal to the airline and avoid future acquisition costs (Krafft \& Mantrala, 2006). Customer awards are usually documented in credit points per booking, which can be redeemed from a certain threshold onwards. Initiated in 1981 (Peacock, 2019), FFP experienced rapid growth and expansion to further sectors in the 1990ies. Today most passengers - frequent flyers or not - participate in an FFP, which questions the status and financial effect of the programs from an airline perspective

${ }^{*}$ corresponding author: Mark Wever

†email: m.w.84@outlook.com 
(Peacock, 2019). Usually managed as individual profit centers, recently, the efficiency of FFP has increasingly been put into question, and steps have been taken to reduce expenses by cutting customer services or increasing redemption barriers for accumulated credits (Pandit, 2015).

Customers are at first sight, fascinated by the opportunity to collect credits and the potential status increase. $77 \%$ of all FFP members would be willing to pay a premium just to join the program (Crowd Twist, 2018). Customers, however, are partly disappointed with the restrictive and frequently changing redemption conditions (Tripathi, Gupta, \& Mazumder, 2018). Airlines increasingly inculcate that most accrued points will never reach the redemption threshold (Price Water House Coopers, 2016). This behavior disillusions customers, is harmful to airlines' image, and plays at the hands of low-cost carriers, offering cheap fares without doubtful loyalty programs (Saxon \& Spickenreuther, 2018). Experts in the airline sector doubt whether FFP supports airlines marketing policy effectively and are uncertain on necessary conditions to maximize program impact on target customers.

\section{Objectives and Methods}

The study aim is to evaluate design elements of FFP concerning their effectiveness to marketing, to advise airlines on how to devise their FFP incentive system to maximize its customer impact. The study comprises a review and an empirical section to derive research hypotheses, which are then tested in a quantitative consumer survey (Saxon \& Spickenreuther, 2018).

The review comprises three operational steps: First, systematics of previously observed consumer impacts is extracted from empirical academic research in order to classify a target system. Second, the design elements of FFP that have been evaluated previously in academic research are classified. Third potential controlling factors moderating the impact of design elements are systematized. The empirical part operationalizes the parameters and defines a sample of Germany-based airline consumers to be surveyed. The analysis uses reliability tested constructs and regression modeling to test the hypotheses. Conclusions concerning effective FFP design are drawn, and airlines are advised to draft their FFP accordingly.

\section{THE CONCEPT OF FFP- MARKETING PRACTICE AND EM- PIRICAL IMPACTS}

\section{Frequent Flyer Programs in Marketing Practice}

FFP is incentive programs that encourage customers flying with an airline to collect credit points (equally called miles, kilometers, or segments). These miles can be redeemed as gratifications for later air travel or other products from the airline itself or affiliated aviation partners", e.g., hotels, car hirers, etc (De Boer \& Gudmundsson, 2012), which can again award credit points to their customers, who then recollect these bonuses with other partners or the airline (Klophaus, 2005). Bonus points are equally used by credit card companies. They buy miles from the airlines, and customers are awarded credits when using a credit card linked to the system (European Central Bank, 2018). FFP thus basically comprises two columns: the status miles system, based on the total amount of miles traveled and consumptions made in a certain period (e.g., the recent year), and the bonus miles system, as a rebate for the previous booking, which can be retrieved once (Knorr, 2019; Recamadas, 2018).

Since the 1980ies, FFP has become a sort of a virtual internal currency system, including airlines issuing and refunding FFP, external business trading partners, accepting FFP as vouchers, and FFP customers who are buying FFP from the airline and consuming them for air-traffic related and other mostly travel-related services (Mankin \& Jewell, 2015; Vinod, 2011). The inclusion of a broad partner network is essential to FFP image and attractiveness (De Boer \& Gudmundsson, 2012).

From an airline perspective, FFP offers many opportunities: FFP allows customers to participate in airlines' transaction cost savings by incentivizing customers to return to redeem the promise FFP makes (Araujo \& Kjellberg, 2015). FFP encourage customers to upgrade their travel (e.g., to business or first class) in order to achieve bonus points. The upgrade means high additional revenues for airlines (Pandit, 2015). Implicit tax advantages have contributed to the popularity of the mileage system: Business flights are usually paid by employers but booked via employee's personal credit cards, which results in an assignment of miles to the card holder's private account. These benefits are hard to track and remain untaxed in some countries. Businesses participating in the bonus point system benefit from the additional turnovers these semi-legal tax-free gratifications generate for employees (Mankin \& Jewell, 2015; Rafiah \& Ariyanti, 2017).

Zuo, Xiong, Wang, and Iida (2018) assign FFP a "gamification effect." High program complexity keeps participants engaged with the brands involved and motivates them to make additional purchases to gain indirect future awards. Airlines build their brand image by offering VIP customers additional visible amenities, e.g., lounges and purchase points in airports (Pandit, 2015). Airlines' marketing benefits 
from FFP by retrieving large amounts of customer data that reveal travel behavior and consumption habits. This information supports the design of new individualized marketing campaigns (Knorr, 2019).

However, recent alternations in FFP schemes have, to some extent, shattered the trust of customers in the system and played into the hands of low-cost carriers: The strategy of billing additional services per flight is partly perceived as more transparent. Customers are disappointed if mileage redemption patterns are changed, and customers flying irregularly abandon their loyalty to the FFP and switch to lowcost carriers. FFP then faces the problem of profitability: The provision of additional amenities has to be matched by additional revenues. If miles are accrued but not redeemed, the system loses in attractiveness for its cooperation partners (Pandit, 2015). Airlines are challenged to avoid a loss of FFP attractiveness by good design.

\section{Design Elements of FFP}

To assess which elements in FFP make the programs successful, a classification of FFP building blocks is useful. FFP effectively combines monetary, service, and status rewards. Additional frequently discussed quality aspects are reach (i.e., network breadth) and transparency of redemption. The following observations are extracted from earlier empirical studies systematically and are condensed into research hypotheses:

\section{Monetary rewards}

So-called "tangible rewards," i.e., material benefits for repeated bookings, enhance customers' relationship quality with the brand (Pandit, 2015). Price rebates indicate airline fairness among all passenger groups analyzed in a mixed hotel and airline customer survey; price increases impair fairness perception (Mimouni-Chaabane \& Volle, 2010). Monetary savings outweigh service and social benefits; only recognition benefits are more effective (Mimouni-Chaabane $\&$ Volle, 2010). These observations result in the first hypothesis.

H1: Availability and height of monetary rewards in FFP positively impact customer behavior

\section{Service rewards}

The term "service rewards" refers to additional services FFP passengers can receive free from a charge or against credit points and differentiate FFP passengers from conventional travelers (Mathies, Gudergan, \& Wang, 2013). Among Chinese passengers, preferential treatment significantly enhances perceived relationship quality but does not increase undesired customer entitlement (Ma, Li, \& Zhang, 2018).
Exploration and entertainment amenities enhance the perceived relationship investment of French FFP passengers and contribute to relationship quality (Mathies et al., 2013). Treatment-based FFP design-elements, e.g., additional contact amenities, are particularly valuable to passengers who estimate interaction value (Kreis \& Mafael, 2014). A second hypothesis summarizes these observations:

H2: Availability and height of service rewards in FFP positively impact customer behavior.

\section{Status rewards}

Among Chinese passengers perceived status is the most effective tool to enhance relationship quality, but equally contributes to (undesired) customer entitlement, which reduces relationship quality if customer expectancies are not met (Ma et al., 2018). Turkish airline customers prefer intangible to monetary benefits, and loyalty development depends on intangible benefits to a large extent (Colakoglu \& Artuger, 2013). Perceived and overt recognition significantly enhances perceived relationship quality among French members of flight loyalty programs (Mimouni-Chaabane \& Volle, 2010). Customers on their way to elite status prefer the airline if this effectuates access. The effect is valid, even if the company offers worse service or is more expensive than competitors (Orhun \& Guo, 2018). Rapid previous status advancements induce passengers to book repeatedly to develop an even higher FFP status (Orhun \& Guo, 2018). Australian passengers pay a price premium in order to attain the premium status (Gao, Carrigg, Lewinski, Polderman, \& Tkalcevic, 2018). Hypothesis 3 brings these observations together:

H3: Availability and height of status rewards in FFP positively impact customer behavior.

\section{Reach of FFP}

Yan and Cui (2016) find the number of partners a highly significant positive regressor on FFP popularity. A comparison of loyalty programs available in the Baltic states confirms that customers prefer programs with high numbers of affiliated partners with the result that the respective airlines realize higher profits (Vilkaite-Vaitone \& Papsiene, 2016). This observation is condensed in hypothesis 4 .

H4: High range and reach of FFP partner networks positively impact customer behavior.

\section{Transparency of FFP redemption}

High redemption requirements for FFP top tier s affect the popularity of hotel and airline sector loyalty programs negatively (Yan \& Cui, 2016). Validity limits to monetary advantages a additional payable upgrades, for which miles are re- 
quired, are perceived unfair and reduce airline popularity among customers in the airline and hotel sector (Mathies et al., 2013). Passengers facing difficulties in redeeming rewards due to limited availability despite FFP status lose their commitment to the airline (Whyte, 2003). Hypothesis 5 reformulates these observations positively:

H5: Transparent redemption conditions in FFP positively impact customer behavior.

\section{Empirically Confirmed Impacts of FFP}

To assess what precisely "positive impact on customer behavior" implies, prior academic research is evaluated to differentiateconsumer behavior impacts. The observed effects usually draw on well-known purchase funnel models (De Pelsmacker, Geuens, \& Van den Bergh, 2007; Koschnick, 1983; Kotler, Keller, \& Bliemel, 2007) and are classified into six impact levels here.

\section{Customer attitude}

FFP influences customers' cognitive, emotional and conative attitudes on the airline. Reward schemes establish positive sentiments in consumers' minds (Tanford, 2013).

\section{Brand image}

The construction of a distinctive brand image is of particular relevance for the highly competitive aviation sector, which disposes of little differentiate necessaryessential products (Ponnam, 2007). FFP shave strengthened customers' image perception of the airline brand (De Boer \& Gudmundsson, 2012; Kalligiannis, Iatrou, \& Mason, 2006). Incentives contribute to enhance frequent flyers' attitude toward the brands, and in the extended run members get convinced of the brand image (Dekay, Toh, \& Raven, 2009). Frequent flyers in FFP feel that their membership generates personal status, service, and monetary value (Dekay et al., 2009).

\section{Purchase behavior}

Choosing between airlines of equal flight schedule and availability, passengers prefer companies offering additional amenities and services (Tanford, 2013). They return to the company due to initial fairness perception and in the conviction that this prior treatment will repeat in the framework of an FFP (Mimouni-Chaabane \& Volle, 2010). Satisfaction with the airline determines consumers' future booking intentions and results from perceived pricing and service quality during recent flights (Park, MacInnis, Priester, Eisingerich, \& Iacobucci, 2010). FFP has been found to contribute to airlines' economic success since they push booking figures, returns per booking (due to higher realized booking prices) (Hossain, Kibria, Farhana, et al., 2017), and market shares (Orhun \& Guo, 2018). These factors finally contribute to increased profitability (Vilkaite-Vaitone \& Papsiene, 2016).

\section{Consumer loyalty}

FFP passengers are awarded a superior status and enjoy an elite in-group (Zuo et al., 2018). Perceived high relationship investments of the airline, e.g., when customers experience monetary savings, service advantages, status, and social benefits induce customer satisfaction (Mimouni-Chaabane \& Volle, 2010). Frequent flyer programs increase customers' bond to the airline. FFP reward systems motivate passengers to re-book with the respective airlines, which promises further (extrinsic) rewards and contributes to establishing customers' overt status (Meyer-Waarden, 2008). FFP makes customers return to belong to a perceived elite (Orhun \& Guo, 2018).

\section{Customer relationship}

Airlines relationship investments in customers realized by FFP significantly enhancing relationship quality and a longlasting, trusting customer partnership (Mimouni-Chaabane \& Volle, 2010). FFP enhances customer loyalty and advocacy partly due to habituation and partly due to the conviction that the FFP offers superior service (Uncles, Dowling, \& Hammond, 2003). Additional rewards for frequent bookings, heighten customers' switching barrier with every booked flight. The impending decay of credit points in case of non-usage over one to three years additionally motivates customers to stay loyal just not to lose the premium acquired over several years (Woisetschlaeger, Michaelis, \& Backhaus, 2008). Customers' keep engaged in the relationship to the brand for a prolonged period by, for instance, joining the brand on virtual media and keeping informed on new products and services.

\section{Customer lifetime value}

Satisfied by superior service, FFP customers actively communicate their conviction of the airline brand and FFP status with friends and colleagues and perhaps share bonus points (Rapp, 2000). Conventional passengers are likely to develop the desire to attain the same superior treatment and equally stay loyal to the airline to progress to VIP status (Zins, 2001). Loyal and satisfied customers represent a vital value base for airlines: A broad FFP customer base means a sustainable competitive advantage to businesses in the aviation industry (Colakoglu \& Artuger, 2013). Investments into FFP now flow back to the provider.

The observed impact levels are the target parameters in the empirical analysis implemented in this study and concretize 
$\mathrm{H} 1$ to $\mathrm{H} 5$ concerning the tested impacts to the target parameters customer attitude, brand image, purchase behavior, consumer loyalty, customer relationship, customer lifetime value.

\section{Moderators to FFP Effectiveness}

Previous research discusses a broad range of moderators of perceived FFP quality and marketing effectiveness, i.e., factors that are not directly related to the FFP but still impact customer behavior. Airline safety and quality and passengers' flying habits are among the most frequently tested factors:

\section{Airline safety and quality}

Attractive schedules and flight flexibility increase the attractiveness of FFP to passengers (Lederman, 2007). Airlines' service quality and safety positively moderate consumers' satisfaction with the airline as a whole and with FFP programs (Sandada \& Matibiri, 2016). Service quality and safety equally enhance passenger satisfaction and airline image (Park et al., 2010). Customer loyalty increases when passengers feel reassured concerning safety and are convinced by service quality (Sandada \& Matibiri, 2016).

\section{Passenger flying habits}

Moderate the impact of FFP design on consumers. Business travelers are more willing to pay for additional FFP amenities than leisure travelers since businesses frequently pay for their employees' travel expenses and do not impose clear restrictions on the budget (Orhun \& Guo, 2018). FP programs' availability is more critical to the long haul and business travelers than leisure and short-haul travelers (Chin, 2002). According to Meyer-Waarden (2008), heavy flyers enjoy social and relational benefits, while rare flyers are mostly budget-optimizing. Since frequent travelers are often registered on one or the other loyalty program already, they are open to join other programs, if those cooperate or offer joint reward systems, for instance, hotel and airline loyalty programs (Dekay et al., 2009; Lederman, 2007).

\section{Research Gap}

Although the review of previous studies has provided a plausible and comprehensive model of the way FFP takes effect on consumer behavior, several research gaps remain which motivate the empirical section of this study:

Although various empirical studies in particular nations, namely in an Australian (Gao et al., 2018; Whyte, 2003) and Chinese (Ma et al., 2018) and even a Baltic (Vilkaite-Vaitone \& Papsiene, 2016), South African (Sandada \& Matibiri, 2016) and Turkish (Colakoglu \& Artuger, 2013) context are available, none of the papers considers German passengers or German airlines FFP or the context of travelers in Germany. Most studies do not differentiate on the design of FFPs (loyalty programs), but assess the impact of pure FFP availability only (Colakoglu \& Artuger, 2013; Lederman, 2007; Meyer-Waarden, 2008; Whyte, 2003; Mathies et al., 2013; Sandada \& Matibiri, 2016).

Most studies focus either on customer attitudes and perception (Dekay et al., 2009; Mathies et al., 2013), branding (Park et al., 2010), purchase theory (Gao et al., 2018; Orhun \& Guo, 2018; Meyer-Waarden, 2008), customer loyalty (Dekay et al., 2009; Sandada \& Matibiri, 2016; MimouniChaabane \& Volle, 2010) or customer relationship management but do not integrate these theoretical perspectives.

\section{EMPIRICAL ANALYSIS}

The empirical study section focuses on the German FFP market and analyses a comprehensive set of FFP design elements and a conclusive set of impacts.

\section{Sample and Survey Design}

A quantitative empirical survey among members of frequent flyer programs with German airlines is conducted in order to assess to what extent design elements of FFP impact consumer behavior and to identify moderators to this effect.

The German aviation market is intensely concentrated and dominated by Lufthansa AG, which together with its $100 \%$ daughters Germanwings and Eurowings transports $86.9 \%$ of passengers booking with German Airlines. While Lufthansa AG does line and charter flights, the competitor's Condor and TUI Fly operate in the charter business only. Due to this strong concentration, there is only one relevant FFP for the German market, in which all resident airlines in the DACH region (German-Austria, and Switzerland) join the Miles \& More Program. Miles \& More is Europe's largest FFP and includes diverse partners, 37 international airlines, thousands of hotels, travel, mobility, entertainment shopping, and finance providers. Miles can be earned and redeemed with every partner of Miles \& More, for instance when booking flights, hotels, rented cars, or for shopping with partner corporations (Lufthansa Group, 2019).

Most earlier studies address FFP customers to assess the effectiveness of FFP schemes scheme (Colakoglu \& Artuger, 2013; Gao et al., 2018; Kreis \& Mafael, 2014; Mathies et al., 2013; Ma et al., 2018; Sandada \& Matibiri, 2016). To reach the target group of FFP customers resident in Germany, the quantitative survey is done among participants of the Miles \& More program. Based on a multiple-choice 
questionnaire, an explanatory factor analysis and a regression model is drafted to test the hypotheses.

For efficient data collection, the survey is conducted electronically via a Web protocol. The surveyor uses Twitter to promote the academic survey. A tweet including the link on the is placed in the category "Miles \& More Lufthansa." Only participants indicating to be a member of Miles \& More are admitted to the remainder of the survey.

The analysis is done at a confidence level of 95\% (resulting z-score 1.96) and accepts a margin of error of $5 \%$. The population size is the total number of Miles \& More members. Miles \& More currently has got 30 million members (Luxury Travel Expert, 2-19). Accordingly, a sample size of 385 is required, and 502 complete answers are collected. The survey questions are formulated as positive test statements and coded on a five-level Likert scale. The survey adapts previously validated coding systems (Bauer, Mäder, \& Huber, 2002; Colakoglu \& Artuger, 2013; Kreis \& Mafael, 2014; Ma et al., 2018; Meyer-Waarden, 2008; Park et al., 2010) for the application in the context of Miles \& More. To assess the input factors, moderators, and target factors according to the hypotheses, multi-item constructs are formed, comprising the replies to several research questions each. These are condensed using factor analytical methods, and construct reliability is checked on the basis of Cronbach Alpha.

\section{Factor Reliability and Descriptive Empirical Results}

The descriptive results by item are displayed in the appendix. The analysis has reliably reached the target group of frequently flying customers: $55 \%$ of the participants are between 30 and 49 years of age. Only $7 \%$ are younger than 20 or older than 60 years. The majority of the participants earn more than 81,000 Euros per year, while only $15 \%$ earn 40 TEUR or less. On average, the participants are in income group 5 (mean 5.11), which indicates an average income of 61 to 80 TEUR. The majority of participants travel mainly for personal reasons. Most (45\%) book less than $10 \%$ of their flights for business reasons. Only 19\% book more than $50 \%$ of business flights. The participants partly book short term trips (30\%), another 29\% however books less than $20 \%$ short term trips. Most participants (39\% or 197 persons) fly more than 25 times per year. Only $0.8 \%$ or 84 persons fly once or twice a year only. $75 \%$ fly at least seven times per year. Correspondingly most $(47 \%)$ of participants are members of several FFP. Only $12 \%$ have always been Miles \& More members only.

Participants' perception of height and availability of premia (AM) is mixed. The majority (41\%) find the FFP premia and redemption options partly attractive. Most, however, do not find available upgrades, beautiful (41\%). Most are not content at all on non-flight purchase and booking options (40\%). Most participants are not particularly satisfied with FFP services; about $25 \%$ do not agree with the respective test statements at all, about a quarter of the participants do not at all feel any superior or important status as FFP members, another $35 \%$ hardly agrees to the respective test statements. Only about $12 \%$ widely or thoroughly feels positive impact of status awards. However, the majority of participants estimate the advantages of the comprehensive partner network with other airlines. It is partly satisfied with the range of partnering hotels and shopping options worldwide. The majority of participants are only partly satisfied with the transparency of redemption and the flexibility of acquired miles. About $10 \%$ each are very satisfied or not satisfied at all. The participants are widely or fully satisfied with airline safety on average. Airline quality perception is mainly positive, but only 3 to $9 \%$ of the participants are delighted. Summarizing the results for the impact of FFP by item, the participants are relatively optimistic on the program's usefulness however they see its brand value and image as comparatively low. This does not impair their intention to make further use of the program, but possibly their recommendation behavior.

The constructs relevant to evaluate the hypotheses comprise premia height and availability (AM), availability and range of service wards (AS), and status awards (AT), perceived range of partner networks (QP), and perceived transparency of redemption (QT). Items assessing moderators of FFP impact comprise perceived airline safety (MAS) and general airline quality (MAQ). The target parameters describing consumer behavior comprise customer attitude on the FFP (BA), Brand Image (BI), Purchase Behavior (BV), Brand Loyalty (BL), customer relationship (BR), and perceived customer lifetime value (BV). Cronbach Alpha assesses the contingency of the construct as a whole. Values above 0.7 are acceptable, and all constructs, but MAS (0.675) are above this bottom line (Nunally \& Bernstein, 1978). Since the deviation is low, MAS is accepted for further evaluation, too. The constructs are approximately generally distributed according to Shapiro Wilk and Kolmogorov-Smirnoff test. Correlations between the input factors are insignificant. Regression modeling is thus admissible.

\section{Hypotheses Test}

The regression models assess the impact of the input factors and moderators on the target factors $\mathrm{BA}, \mathrm{BI}, \mathrm{BV}, \mathrm{BL}, \mathrm{BR}$, and $\mathrm{BV}$. The following tables contain significant effects only. 
H1 (monetary premia): Table 1 summarizes the significant results of standardized beta values for $\mathrm{H} 5$ only. It shows that AM (height and availability of monetary premia) takes a highly significant positive effect on all target factors in the customer behavior chain. H1 is entirely accepted. The number of flights per year is a positive and the usage of other FFP a negative control of the impact of monetary premia. Airline safety has got a significant moderating effect on customer attitude, brand image and purchase behavior. Airline safety and quality unfold direct impacts on customer loyalty, relationship, and customer value,. Still, they are not moderators concerning the effect of AM on the customer behavior chain (Indicated by numbers in brackets).

TABLE 1. Test of H1

\begin{tabular}{lllllll}
\hline \hline H1 & AM & MC1 & MT3 & MT4 & MAS & MAQ \\
\hline Sig Beta stand & Monetary Premia & Age Group & The Annual Number of Flights & Other FFP & Airline Safety & Airline Quality \\
\hline BA & $0.390^{* *}$ & & & $-0.226^{* *}$ & $0.167^{* *}$ & \\
BI & $0.179^{* *}$ & & $-0.179^{* *}$ & $0.178^{* *}$ & $0.105^{* *}$ \\
BP & $0.115^{* *}$ & $0.133^{* *}$ & $-0.192^{* *}$ & $0.118^{* *}$ & $(0.265)$ \\
BL & $0.179^{* *}$ & & $0.141^{* *}$ & $-0.233^{* *}$ & $(0.333)$ \\
BR & $0.236^{* *}$ & & & & $(0.227)$ & $(0.290)$ \\
BV & $0.410^{* *}$ & $-0.062^{*}$ & $0.066^{*}$ & $-0.094^{*}$ & $(0.012)$ & $(0.238)$ \\
\hline \hline
\end{tabular}

H2 (service awards): Summarizing the results of the six individual regression models drafted to test $\mathrm{H} 2$ (Table 2), this hypothesis is accepted. AS is a highly significant positive determiner in all six models and more important than all other determiners, controls and moderators and impacts consumer behavior positively:

TABLE 2. Test of $\mathrm{H} 2$

\begin{tabular}{lllllll}
\hline \hline H2 & AS & MT2 & MT3 & MT4 & MAS & MAQ \\
\hline Sig Beta stand & Service Award & Short Distance Flights & The Annual Number of Flights & Other FFP & Airline Safety & Airline Quality \\
\hline BA & $0.385^{* *}$ & & & $-0.209^{* *}$ & & $(0.165)$ \\
BI & $0.349^{* *}$ & & & $-0.104^{* *}$ & $0.120^{* *}$ \\
BP & $0.170^{* *}$ & $0.076^{* *}$ & $0.097^{*}$ & $-0.185^{* *}$ & $(0.252)$ \\
BL & $0.301^{* *}$ & $0.054^{* *}$ & & $-0.218^{* *}$ & $(0.236)$ \\
BR & $0.228^{* *}$ & & & $-0.084^{* *}$ & $0.140^{* *}$ & $(0.304)$ \\
BV & $0.384^{* *}$ & & & & & $(0.255)$ \\
\hline \hline
\end{tabular}

H3 (status awards): According to H3, the relevance of status awards to consumer behavior is evaluated, and the results are represented in Table 3 . Hypothesis 3 is entirely accepted. The availability and height of status awards in FFP, influences consumer behavior positively. AT is a highly significant determiner in all six models and more important than all other determiners, controls and moderators.

TABLE 3. Test of $\mathrm{H} 3$

\begin{tabular}{cllllll}
\hline \hline H3 & AT & MT2 & MT3 & MT4 & MAS & MAQ \\
\hline Sig Beta stand & Service Award & Short Distance Flights & The Annual Number of Flights & Other FFP & Airline Safety & Airline Quality \\
\hline BA & $0.325^{* *}$ & & & $-0.220^{* *}$ & & $(0.208)$ \\
BI & $0.384^{* *}$ & $0.058^{* *}$ & & $-0.105^{* *}$ & $(0.122)$ & $(0.117)$ \\
BP & $0.288^{* *}$ & $0.087^{* *}$ & $0.094^{*}$ & $-0.177^{* *}$ & $(0.104)$ & $(0.201)$ \\
BL & $0.315^{* *}$ & $0.064^{* *}$ & & $-0.221^{* *}$ & & $(0.2950$ \\
BR & $0.326^{* *}$ & & & & $(0.217)$ & $(0.278)$ \\
BV & $0.360^{* *}$ & & & $-0.090^{*}$ & $(0.113)$ & $(0.288)$ \\
\hline \hline
\end{tabular}

H4 (reach of FFP network): The summative results of the six regression models assessing the assumedly positive impact of FFP reach on consumer behavior are displayed in Table 4: H4 is fully assumed, the range and quality of partner net- works take a significantly positive effect on consumer behavior. All beta factors of QP are highly significant, and all regression models show highly significant fits. 
TABLE 4. Test of H4

\begin{tabular}{|c|c|c|c|c|c|c|}
\hline H4 & QP & MT2 & MT3 & MT4 & MAS & MAQ \\
\hline Sig Beta stand & Range of Partner Networks in FFP & Short Distance Flights & The Annual Number of Flights & Other FFP & Airline Safety & Airline Quality \\
\hline BA & $0.201^{* *}$ & & $0.073^{*}$ & $-0.232^{* *}$ & & $(0.264)$ \\
\hline BI & $0.297^{* *}$ & & & $-0.122 * *$ & $(0.130)$ & $(0.166)$ \\
\hline ВР & $0.128^{* *}$ & $0.069^{*}$ & $0.142^{* *}$ & $-0.191 * *$ & $(0.090)$ & $(0.250)$ \\
\hline BL & $0.220^{* *}$ & & $0.111^{* *}$ & $-0.236^{* *}$ & & $(0.347)$ \\
\hline BR & $0.270^{* *}$ & & & & $(0.223)$ & $(0.317)$ \\
\hline BV & $0.161^{* *}$ & & $0.029^{*}$ & $-0.105^{* *}$ & $(0.119)$ & $(0.378)$ \\
\hline
\end{tabular}

H5 (transparency of redemption): A synopsis of the regression models comprising the factor QT (transparency of redemption) illustrates that this is another essential deter- miner of desirable customer behavior. QT is highly significant in all six tested models.

TABLE 5. Test of H5

\begin{tabular}{|c|c|c|c|c|c|c|}
\hline H4 & QT & MT2 & MT3 & MT4 & MAS & MAQ \\
\hline Sig Beta stand & Transparency of Redemption & Short Distance Flights & The Annual Number of Flights & Other FFP & Airline Safety & Airline Quality \\
\hline $\mathrm{BA}$ & $0.246^{*}+$ & & $0.049^{*}$ & $-0.244^{* *}$ & & $(0.246)$ \\
\hline BI & $0.282^{* *}$ & & & $-0.134^{* *}$ & $(0.143)$ & $0.174^{* *}$ \\
\hline BP & $0.140^{* *}$ & $0.078^{*}$ & $0.138^{* *}$ & $0.140^{* *}$ & $0.113^{* *}$ & $(0.272)$ \\
\hline BL & $0.174^{* *}$ & $0.058^{*}$ & $0.111^{* *}$ & $-0.242^{* *}$ & & $(0.357)$ \\
\hline BR & $0.231^{* *}$ & & & & $(0.231)$ & $(0.319)$ \\
\hline BV & 0.323 & & $0.078^{* *}$ & $-0.115^{* *}$ & $(0.093)$ & $0.322^{* *}$ \\
\hline
\end{tabular}

\section{Impact of moderators}

Summarizing the results concerning the assumed moderators across all models, consumers doing a high number of short-distance flights (MT2) are usually more inclined to book with the airline and show higher customer loyalty. They partly perceive the higher brand image. A high number of annual flights (MT3) is a positive predictor of consumers FFP related desirable behavior. Frequent flyers develop an improved brand attitude, book with the airline more frequently, are more loyal, and equally unfold higher customer value. Membership in other FFP (MT4) is a negative moderator of customer behavior towards Miles \& More and more often highly significant than all other moderators. Customers who have other FFP at their disposal show a more negative brand attitude, perceive the brand image of Miles \& less valuable, book less frequently, are less loyal, and unfold lower customer value than passengers trusting in Miles \& More alone.

Perceived airline safety positively moderates the impact of FFP design on customer behavior. Only a few models find an actualreal moderating effect in the way that both airline safety as a factor and the interaction variable with the determiner are significant. This is the case for four from twenty-four models only. For most models, airline safety is a highly significant determiner, but not a moderator of the consumer behavior target. This is the case in 14 of 24 cases. Airline quality rarely is a moderator of the impact of FFP on consumer behavior. This assumption is only confirmed for four out of 24 models. In 21 cases, airline quality is a significant co-determiner of customer behavior since the respective interaction variables are not significant. In sum, apart from FFP program attractiveness, perceived airline safety and quality are essential positive co-determiners of customer behavior in the aviation business, but not moderators in the original sense.

\section{CONCLUSION}

\section{Classification of Results}

The study has combined a thorough review of previous empirical research in the consumer impact of FFP and a statistically representative empirical member survey on determiners of FFP effectiveness for the only German FFP program Miles \& More.

Consumer behavior constructs and the design elements of FFP have conclusively been derived from earlier models, and it has been found that height and availability of monetary awards, availability, and range of service awards and status awards, the number of FFP partners, and redemption transparency are the major design elements of frequent flyer programs. The impact of these parameters on consumer behavior has been tested, referring to six frequently discussed elements in the purchase funnel. The survey finds that all six factors are important to each level of the consumer behavior chain. Partly airline safety and airline quality are significant co-determinants to consumer behavior. A high number of annual flights and a high share of short-distance flights increases the behavioral impact of FFP, while membership in other FFP is a very important negative control.

The study distinguishes from earlier research concerning 
its focus on the German FFP sector and concerning the comprehensiveness of assessment of FFP design elements and behavioral impacts. The found relationships, of course, are valid for the German aviation sector only. Regression modeling is a proven approach applied by several similar studies. Still, it does not show cross relationships between the input factors and moderators (which have, however, been found insignificant in the preliminary analysis). Further studies in FFP impact analysis should use a more complex and comprehensive statistical design, e.g., structural equation modeling, to discover different and more distinct relationships.

\section{Recommendations to Airline Marketing Practice}

Airlines benefit from the survey results among 502 Miles \& More members to improve and adjust their FFP programs: The study has found that all levels of the customer behavior cycle are addressed by FFP. FFP takes effect on customer attitude, contribute to develop airlines' brand image, motivates flight bookings, and keeps customers loyal to the airline. They build a sustainable customer relationship based on mutual valuation. Contrary to frequent criticism (De Boer \& Gudmundsson, 2012; Knorr, 2019; Klophaus, 2005; Vinod, 2011), FFP is still an effective strategy of gaining, developing, and retaining customers.

However, airlines should not reduce the comprehensive draft of their FFP, to save costs at short notice: the analysis has shown that price premia, service, and status awards are integral elements of FFP and together contribute to impact customer behavior. It is not a single FFP element that is effective by itself or redundant. FFP is rather defined as comprehensive service and premia concepts. Customers perceive FFP as a compliment for their trust and loyalty. If airlines reduce one or the other benefit for budget reasons, they undermine the credibility of the whole program.

Network reach, i.e. the number of available partners and redemption transparency, are highly significant determiners of FFP effectiveness with customers. Airlines should accordingly build their FFP network and gain other airlines, hotels, and shops around the world to participate with attractive and transparent offers. Redemption guideless should be kept possibly simple and inform customers on premia height and expiry. Hidden conditions and repeated changes in redemption conditions, while the program is running should be avoided to maintain customer trust.

Beyond the development of FFP, airlines should keep general quality and safety standards in mind. These are the probably most important determiners of customer booking behavior, trust, and loyalty. So far, brand airlines still enjoy an advance of trust concerning safety and quality criteria. But budget carriers could, in the mid-term, catch up on these points. FFP remains an important strategy to maintain the attraction of brand airlines but should be designed honestly and sustainably.

\section{REFERENCES}

Airliners. (2020). Corona virus. Retrieved from https://bit.ly/3raKfbl

Araujo, L., \& Kjellberg, H. (2015). Forming cognitions by investing in a form: Frequent flyer programs in US air travel postderegulation (1981-1991). Industrial Marketing Management, 48, 68-78. doi:https://doi.org/10.1016/j.indmarman .2015 .03 .006

Bauer, H. H., Mäder, R., \& Huber, F. (2002). Markenpersönlichkeit als determinante von markenloyalität. Schmalenbachs Zeitschrift für betriebswirtschaftliche Forschung, 54(8), 687-709. doi:https://doi.org/10.1007/BF03372692

Chin, A. T. (2002). Impact of frequent flyer programs on the demand for air travel. Journal of Air Transportation, 7(2), 53-86. doi:https://doi.org/10.1016/j.tra.2015.07.007

Colakoglu, 0., \& Artuger, S. (2013). The effect of frequent flyer program on customer loyalty. The International of Social Sciences, 12(1), 33-43.

Crowd Twist. (2018). Crowd twist consumer loyalty study shows $87 \%$ of gen z consumers want omnichannel loyalty programs. Retrieved from https://prn.to/3nzBtS5

De Boer, E. R., \& Gudmundsson, S. V. (2012). 30 years of frequent flyer programs. Journal of Air Transport Management, 24, 18-24. doi:https://doi.org/10.1016/j.jairtraman.2012.05.003

Dekay, F., Toh, R. S., \& Raven, P. (2009). Loyalty programs: Airlines outdo hotels. Cornell Hospitality Quarterly, 50(3), 371-382. doi:https://doi.org/10.1177/1938965509338780

De Pelsmacker, P., Geuens, M., \& Van den Bergh, J. (2007). Marketing communications: A European perspective. New York, NY: Pearson education.

European Central Bank. (2018). Virtual currency schemes. Retrieved from https ://bit. ly/3nCQX7Y 
Gao, Y., Carrigg, M., Lewinski, R., Polderman, D., \& Tkalcevic, P. (2018). The perceived value of frequent flyer program benefits among Australian travelers. International Journal of Aviation, Aeronautics, and Aerospace, 5(3), 6-10. doi: https://doi.org/10.15394/ijaaa.2018.1249

Hossain, M. Z., Kibria, H., Farhana, S., et al. (2017). Do customer loyalty programs really work in airlines business? A study on air Berlin. Journal of Service Science and Management, 10(04), 360-375. doi:https://doi.org/10.4236/jssm.2017 .104029

International Air Transport Association. (2017). Airport competition: Myth or reality? Retrieved from https://bit.ly/ 3h9xCJ6

Kalligiannis, K., Iatrou, K., \& Mason, K. (2006). How do airlines perceive that strategic alliances affect their individual branding? Journal of Air Transportation, 11(2), 45-60.

Klophaus, R. (2005). Frequent flyer programs for European low-cost airlines: Prospects, risks and implementation guidelines. Journal of Air Transport Management, 11(5), 348-353. doi:https://doi.org/10.1016/j.jairtraman.2005.07.001

Knorr, A. (2019). Big data, customer relationship and revenue management in the airline industry: What future role for frequent flyer programs? Review of Integrative Business and Economics Research, 8(2), 38-51.

Koschnick, W. J. (1983). Standard dictionary of advertising, mass media, and marketing, English-German. Berlin, Germany: Walter de Gruyter.

Kotler, P., Keller, K., \& Bliemel, F. (2007). Marketing-management. Munich, Germany: Pearson.

Krafft, M., \& Mantrala, M. K. (2006). Retailing in the 21st century. Berlin, Heidelberg: Springer.

Kreis, H., \& Mafael, A. (2014). The influence of customer loyalty program design on the relationship between customer motives and value perception. Journal of Retailing and Consumer Services, 21(4), 590-600. doi:https://doi.org/10 .1016/j.jretconser.2014.04.006

Kuo, M. P., \& Chen, Y. M. (2015). A study on the relationships among body sensory experience, customer satisfaction and customer loyalty-beauty SPA center as an example. International Journal of Business and Administrative Studies, 1(2), 61-67. doi:https://doi.org/10.20469/ijbas.10003-2

Lederman, M. (2007). Do enhancements to loyalty programs affect demand? The impact of international frequent flyer partnerships on domestic airline demand. The Rand Journal of Economics, 38(4), 1134-1158. doi:https://doi.org/ 10.1111/j.0741-6261.2007.00129.x

Lufthansa Group. (2019). Geschäftsbericht. Retrieved from https://bit.1y/2Wx3D4b

Luxury Travel Expert. (2-19). Review of miles \& more, the frequent flyer program of Lufthansa. Retrieved from https:// bit. ly/3p85LeY

Ma, B., Li, X., \& Zhang, L. (2018). The effects of loyalty programs in services a double-edged sword? Journal of Services Marketing, 32(3), 300-310. doi:https://doi.org/10.1108/JSM-06-2016-0227

Mankin, J. A., \& Jewell, J. J. (2015). Frequent flyer miles as company scrip: Implications on taxation. Business Studies Journal, $7(1), 14-32$.

Mathies, C., Gudergan, S. P., \& Wang, P. Z. (2013). The effects of customer-centric marketing and revenue management on travelers' choices. Journal of Travel Research, 52(4), 479-493.

Meyer-Waarden, L. (2008). The influence of loyalty programme membership on customer purchase behaviour. European Journal of Marketing, 5(6), 34-60. doi:https://doi.org/10.1108/03090560810840925

Mimouni-Chaabane, A., \& Volle, P. (2010). Perceived benefits of loyalty programs: Scale development and implications for relational strategies. Journal of Business Research, 63(1), 32-37. doi:https://doi.org/10.1016/j.jbusres.2009.01.008

Nunally, J. C., \& Bernstein, I. H. (1978). Psychometric theory. New York, NY: McGraw-Hill.

Orhun, A. Y., \& Guo, T. (2018). Reaching for gold: Frequent-flyer status incentives and moral hazard. Retrieved from https:// bit.1y/3mAHTyZ

Pandit, P. (2015). Revitalizing airline loyalty: Frequent flyer programs. Retrieved from https://bit.1y/3r8q91o

Park, C. W., MacInnis, D. J., Priester, J., Eisingerich, A. B., \& Iacobucci, D. (2010). Brand attachment and brand attitude strength: Conceptual and empirical differentiation of two critical brand equity drivers. Journal of Marketing, 74(6), 1-17. doi:https://doi.org/10.1509/jmkg.74.6.1

Peacock, L. (2019). So what's the point? Business Travel. Retrieved from https://bit.1y/2Kz5in7 
Ponnam, A. (2007). Comprehending the strategic brand building framework of kingfisher in the context of brand identity prism. The Journal of Brand Management, 4(4), 63-71.

Powley, T. (2017). European airlines face more cuts and consolidation. Retrieved from https://on.ft.com/3p6Ar0i

Price Water House Coopers. (2016). Aviation perspectives the future of frequent flyer programs: Will you win or lose. Retrieved from https://pwc.to/3rd3P6D

Rafiah, K. K., \& Ariyanti. (2017). Role of transactional quality and relational quality to customer e-loyalty in marketplace C2C in Indonesia. International Journal of Business and Economic Affairs, 2(2), 116--126.

Rapp, R. (2000). Customer relationship marketing in the airline industry. In, Relationship marketing. Berlin, Germany: Springer.

Recamadas, H. K. (2018). A path analysis of customer loyalty of homegrown coffee shops in Davao region. Journal of Administrative and Business Studies, 4(4), 185-195. doi:https://doi.org/10.20474/jabs-4.4.1

Sandada, M., \& Matibiri, B. (2016). An investigation into the impact of service quality, frequent flier programs and safety perception on satisfaction and customer loyalty in the airline industry in Southern Africa. South East European Journal of Economics and Business, 11(1), 41-53. doi:https://doi.org/10.1515/jeb-2016-0006

Saxon, S., \& Spickenreuther, T. (2018). Miles ahead: How to improve airline customer-loyalty programs. Retrieved from https://mck.co/2WqW8Mh

Tagesschau, B. (2020). Tausende stellen bei lufthansa auf der kipp. Retrieved from https://bit.1y/2WvAiqM

Tanford, S. (2013). The impact of tier level on attitudinal and behavioral loyalty of hotel reward program members. International Journal of Hospitality Management, 34, 285-294. doi:https://doi.org/10.1016/j.ijhm.2013.04.006

Tripathi, R., Gupta, N., \& Mazumder, S. (2018). Flying times for airline freuqent flyer prgorams. Retrieved from https:// infy.com/38mws 80

Uncles, M. D., Dowling, G. R., \& Hammond, K. (2003). Customer loyalty and customer loyalty programs. Journal of Consumer Marketing, 20(4), 294-316. doi:https://doi.org/10.1108/07363760310483676

Vilkaite-Vaitone, N., \& Papsiene, P. (2016). Influence of customer loyalty program on organizational performance: A case of airline industry. Engineering Economics, 27(1), 109-116. doi:https://doi.org/10.5755/j01.ee.27.1.10267

Vinod, B. (2011). Unleashing the power of loyalty programs: The next 30 years. Journal of Revenue and Pricing Management, 10(5), 471-476. doi:https://doi.org/10.1057/rpm.2011.11

Whyte, R. (2003). Loyalty marketing and frequent flyer programmes: Attitudes and attributes of corporate travellers. Journal of Vacation Marketing, 9(1), 17-34. doi:https://doi.org/10.1177/135676670200900102

Woisetschlaeger, D., Michaelis, M., \& Backhaus, C. (2008). The "dark side" of brand alliances: How the exit of alliance members affects consumer perceptions. New York, NY: ACR North American Advances.

Yan, W., \& Cui, Z. (2016). Factors contributing to popularity of loyalty programs: evidence from emerging markets. Cornell Hospitality Quarterly, 57(2), 184-192. doi:https://doi.org/10.1177/1938965516636684

Zins, A. H. (2001). Relative attitudes and commitment in customer loyalty models. International Journal of Service Industry Management, 12(3), 269-294. doi:https://doi.org/10.1108/EUM0000000005521

Zuo, L., Xiong, S., Wang, Z., \& Iida, H. (2018). An analysis of gamification effect of frequent-flyer program. In International Conference on E-Learning and Games, Berlin, Germany. 


\section{APPENDIX}

Appenidx: Distributions of frequencies by item

\begin{tabular}{|c|c|c|c|c|c|}
\hline Target Items & Do not Agree at All & Hardly Agree & Partly Agree & Widely Agree & Fully Agree \\
\hline \multicolumn{6}{|l|}{ Brand attitude (BA) } \\
\hline Miles \& More is part of my travels. & $5.18 \%$ & $9.76 \%$ & $31.27 \%$ & $33.86 \%$ & $19.92 \%$ \\
\hline $\begin{array}{l}\text { I feel personally connected to the } \\
\text { Miles \& More program. }\end{array}$ & $13.94 \%$ & $23.11 \%$ & $29.48 \%$ & $24.50 \%$ & $8, .96 \%$ \\
\hline $\begin{array}{l}\text { I feel emotionally bonded to the Miles } \\
\& \text { More program. } \\
\text { Brand Image (BI) }\end{array}$ & $30.48 \%$ & $26.10 \%$ & $21.71 \%$ & $14.94 \%$ & $6.77 \%$ \\
\hline Miles \& More is a unique brand. & $15.34 \%$ & $25.50 \%$ & $32.07 \%$ & $20.92 \%$ & $6.18 \%$ \\
\hline $\begin{array}{l}\text { Miles \& More enjoys high acceptance } \\
\text { among travelers. }\end{array}$ & $5.78 \%$ & $17.93 \%$ & $40.44 \%$ & $28.09 \%$ & $7.77 \%$ \\
\hline $\begin{array}{l}\text { Miles \& More membership mediates a } \\
\text { positive image. } \\
\text { Purchase Behavior (BP) }\end{array}$ & $10.96 \%$ & $24.90 \%$ & $33.07 \%$ & $22.71 \%$ & $8.37 \%$ \\
\hline $\begin{array}{l}\text { I am a regular customer of Miles \& } \\
\text { More partner airlines. }\end{array}$ & $3.98 \%$ & $6,77 \%$ & $22.91 \%$ & $35.06 \%$ & $31.27 \%$ \\
\hline $\begin{array}{l}\text { If I fly again, I will again go with Miles } \\
\& \text { More partner airlines. }\end{array}$ & $3.19 \%$ & $8.76 \%$ & $32.67 \%$ & $31.08 \%$ & $24.30 \%$ \\
\hline $\begin{array}{l}\text { I plan to fly with Miles \& More partner } \\
\text { airlines more frequently in future. } \\
\text { Brand Loyalty (BL) }\end{array}$ & $11.16 \%$ & $26.49 \%$ & $28.88 \%$ & $17.33 \%$ & $16.14 \%$ \\
\hline $\begin{array}{l}\text { I would encourage my family and } \\
\text { friends to go with Miles \& More part- } \\
\text { ner airlines. }\end{array}$ & $12.55 \%$ & $16.93 \%$ & $31.27 \%$ & $24.70 \%$ & $14.54 \%$ \\
\hline $\begin{array}{l}\text { I would be reluctant to book with } \\
\text { non-Miles \& More partners. }\end{array}$ & $29.68 \%$ & $23.71 \%$ & $23.11 \%$ & $11.75 \%$ & $11.75 \%$ \\
\hline $\begin{array}{l}\text { I would encourage my company to } \\
\text { book with Miles \& More partner air- } \\
\text { lines. } \\
\text { customer Relationship (BR) }\end{array}$ & $18.53 \%$ & $20.92 \%$ & $29.08 \%$ & $16.93 \%$ & $14.54 \%$ \\
\hline $\begin{array}{l}\text { I have a high-quality relationship } \\
\text { with Miles \& More partner airlines. }\end{array}$ & $10.76 \%$ & $24.10 \%$ & $34.66 \%$ & $23.11 \%$ & $7.37 \%$ \\
\hline $\begin{array}{l}\text { I have trust in Miles \& More partner } \\
\text { airlines. }\end{array}$ & $3.59 \%$ & $7.17 \%$ & $28.29 \%$ & $44.02 \%$ & $16.93 \%$ \\
\hline $\begin{array}{l}\text { I am willing to remain a customer of } \\
\text { Miles \& More partner airlines. } \\
\text { Brand Value (BV) }\end{array}$ & $3.59 \%$ & $7.77 \%$ & $26.49 \%$ & $38.65 \%$ & $23.51 \%$ \\
\hline $\begin{array}{l}\text { Participating in the Miles \& More pro- } \\
\text { gram makes me feel better about my- } \\
\text { self. }\end{array}$ & $25.50 \%$ & $25.50 \%$ & $28.49 \%$ & $14.94 \%$ & $5.58 \%$ \\
\hline $\begin{array}{l}\text { The Miles \& More program offers me } \\
\text { additional value for my money. }\end{array}$ & $11.35 \%$ & $20.52 \%$ & $39.44 \%$ & $20.52 \%$ & $8.17 \%$ \\
\hline $\begin{array}{l}\text { The Miles \& More program is useful } \\
\text { for me. } \\
\text { Premia height \& availabiltiy (AM) }\end{array}$ & $2.79 \%$ & $11.75 \%$ & $37.05 \%$ & $32.07 \%$ & $16.33 \%$ \\
\hline $\begin{array}{l}\text { Miles \& More provides a favorable } \\
\text { mileage accumulation policy. }\end{array}$ & $9.16 \%$ & $24.50 \%$ & $41.04 \%$ & $21.91 \%$ & $3.39 \%$ \\
\hline $\begin{array}{l}\text { Miles \& More offers attractive up- } \\
\text { grades. }\end{array}$ & $17.53 \%$ & $41.24 \%$ & $27.09 \%$ & $11.75 \%$ & $2.39 \%$ \\
\hline
\end{tabular}


Appenidx: Distributions of frequencies by item

\begin{tabular}{|c|c|c|c|c|c|}
\hline Target Items & Do not Agree at All & Hardly Agree & Partly Agree & Widely Agree & Fully Agree \\
\hline $\begin{array}{l}\text { Miles \& More has convincing redemp- } \\
\text { tion options for flight bookings. }\end{array}$ & $11.55 \%$ & $21.71 \%$ & $42.23 \%$ & $18.53 \%$ & $5.98 \%$ \\
\hline $\begin{array}{l}\text { Miles \& More has attractive premia } \\
\text { for non-flight purchases and book- } \\
\text { ings. } \\
\text { Service range and availability (AS) }\end{array}$ & $39.64 \%$ & $26.49 \%$ & $19.92 \%$ & $9.16 \%$ & $4.78 \%$ \\
\hline $\begin{array}{l}\text { I feel that Miles \& More gives me bet- } \\
\text { ter treatment than it gives customers } \\
\text { who do not join the program. }\end{array}$ & $23.51 \%$ & $29.08 \%$ & $26.69 \%$ & $14.94 \%$ & $5.78 \%$ \\
\hline $\begin{array}{l}\text { I feel that Miles \& More gives me } \\
\text { faster service than it gives customers } \\
\text { who do not join the program. }\end{array}$ & $24.90 \%$ & $25.90 \%$ & $26.49 \%$ & $15.54 \%$ & $7.17 \%$ \\
\hline $\begin{array}{l}\text { I feel that Miles \& More does things } \\
\text { for me that it does not do for most } \\
\text { other customers. } \\
\text { Perception of status awards (AT) }\end{array}$ & $29.68 \%$ & $33.47 \%$ & $26.29 \%$ & $7.57 \%$ & $2.99 \%$ \\
\hline $\begin{array}{l}\text { I feel that I have a high standing as a } \\
\text { member of Miles \& More. }\end{array}$ & $23.31 \%$ & $35.06 \%$ & $26.89 \%$ & $11.95 \%$ & $2.79 \%$ \\
\hline $\begin{array}{l}\text { I believe that I am a very important } \\
\text { customer of Miles \& More partner air- } \\
\text { lines. }\end{array}$ & $28.49 \%$ & $33.86 \%$ & $25.30 \%$ & $8.76 \%$ & $3.59 \%$ \\
\hline $\begin{array}{l}\text { I believe that Miles \& More part- } \\
\text { ner airlines appreciate me more than } \\
\text { most of its other customers. } \\
\text { Range of partner networks (QP) }\end{array}$ & $29.28 \%$ & $37.85 \%$ & $26.69 \%$ & $4.38 \%$ & $1.79 \%$ \\
\hline $\begin{array}{l}\text { Miles \& More has the advantage of } \\
\text { partnering with many airlines glob- } \\
\text { ally. }\end{array}$ & $0.20 \%$ & $3.59 \%$ & $18.33 \%$ & $51.39 \%$ & $26.49 \%$ \\
\hline $\begin{array}{l}\text { Miles \& More has got an extensive } \\
\text { network of attractive hotel partner- } \\
\text { ships. }\end{array}$ & $6.57 \%$ & $19.12 \%$ & $42.03 \%$ & $25.10 \%$ & $7.17 \%$ \\
\hline $\begin{array}{l}\text { Miles \& More offers a broad range of } \\
\text { shopping options worldwide. } \\
\text { Perceived transparency of redemp- } \\
\text { tion (QT) }\end{array}$ & $11.95 \%$ & $24.90 \%$ & $37.25 \%$ & $19.32 \%$ & $6.57 \%$ \\
\hline $\begin{array}{l}\text { I can always redeem collected miles } \\
\text { easily. }\end{array}$ & $12.75 \%$ & $19.32 \%$ & $33.86 \%$ & $24.90 \%$ & $9.16 \%$ \\
\hline $\begin{array}{l}\text { The redemption of miles is transpar- } \\
\text { ent. }\end{array}$ & $9 / .16 \%$ & $19.72 \%$ & $29.48 \%$ & $30.28 \%$ & $11.35 \%$ \\
\hline $\begin{array}{l}\text { You can flexibly use acquired miles. } \\
\text { Moderators (items) } \\
\text { Airline safety (MAS) }\end{array}$ & $9.96 \% 17.53 \%$ & $37.85 \%$ & $25.70 \%$ & $8.96 \%$ & \\
\hline $\begin{array}{l}\text { I am generally satisfied with flight } \\
\text { safety. }\end{array}$ & $0.20 \%$ & $0.20 \%$ & $2.99 \%$ & $37.05 \%$ & $59.56 \%$ \\
\hline $\begin{array}{l}\text { I feel save during flights with Miles \& } \\
\text { More partner airlines. }\end{array}$ & $0.60 \%$ & $0.60 \%$ & $6.77 \%$ & $38.05 \%$ & $53.98 \%$ \\
\hline $\begin{array}{l}\text { I feel the cabin crews at Miles \& More } \\
\text { Partner Airlines are competent and } \\
\text { reliable. }\end{array}$ & $1.20 \%$ & $1.59 \%$ & $20.72 \%$ & $55.58 \%$ & $20.92 \%$ \\
\hline
\end{tabular}


Appenidx: Distributions of frequencies by item

\begin{tabular}{|c|c|c|c|c|c|}
\hline Target Items & Do not Agree at All & Hardly Agree & Partly Agree & Widely Agree & Fully Agree \\
\hline \multicolumn{6}{|l|}{ Airline Quality (MAQ) } \\
\hline $\begin{array}{l}\text { The employee attitude of Miles \& } \\
\text { More partner airlines demonstrates } \\
\text { their willingness to help me. }\end{array}$ & $2.79 \%$ & $4.58 \%$ & $30.08 \%$ & $50.00 \%$ & $12.55 \%$ \\
\hline $\begin{array}{l}\text { The employee attitude of Miles \& } \\
\text { More partner airlines shows me that } \\
\text { they understand my needs. }\end{array}$ & $2.79 \%$ & $9.36 \%$ & $38.45 \%$ & $40.04 \%$ & $9.36 \%$ \\
\hline $\begin{array}{l}\text { The employees of Miles \& More part- } \\
\text { ner airlines are able to handle my } \\
\text { complaints directly and immediately. }\end{array}$ & $8.96 \%$ & $20.32 \%$ & $37.85 \%$ & $25.70 \%$ & $7.17 \%$ \\
\hline $\begin{array}{l}\text { The Miles \& More airlines facility is } \\
\text { well designed. }\end{array}$ & $2.39 \%$ & $9.16 \%$ & $38.05 \%$ & $42.23 \%$ & $8.17 \%$ \\
\hline $\begin{array}{l}\text { I rarely have to wait long to receive } \\
\text { the Miles \& More service. }\end{array}$ & $5.38 \%$ & $16.33 \%$ & $33.27 \%$ & $32.47 \%$ & $12.55 \%$ \\
\hline
\end{tabular}

